\title{
KIF5B wt Allele
}

National Cancer Institute

\section{Source}

National Cancer Institute. KIF5B wt Allele. NCI Thesaurus. Code C101426.

Human KIF5B wild-type allele is located in the vicinity of 10p11.22 and is approximately $47 \mathrm{~kb}$ in length. This allele, which encodes kinesin-1 heavy chain protein, plays a role in vesicle transport. A chromosomal inversion involving this gene and the RET gene may be associated with lung adenocarcinoma. 